\title{
Performance and Evaluation of Power Weeder, Wheel Hoe, Star Weeder under Dryland Conditions
}

\author{
G. Kishore Kumar*, B. Raj Kiran and Ch. Murali Krishna \\ College of Agricultural Engineering, ANGRAU, Bapatla, India \\ *Corresponding author
}

A B S T R A C T

\begin{tabular}{|c|c|}
\hline & \multirow{6}{*}{$\begin{array}{l}\text { Weeding consists of uprooting and removal of unwanted plants which grow in a filed with } \\
\text { a cultivated crop competing with the crops for moisture and plants nutrients. Suitable } \\
\text { mechanization technology is needed to reduce drudgery and to enhance time lines of } \\
\text { operation. Hence a study was conducted to evaluate the performance of power weeder, } \\
\text { wheel hoe and star weeder under dry land condition. Three weeders were initially } \\
\text { evaluated in the dry land planted with maize with a plot size } 20 \mathrm{~m} \times 10 \mathrm{~m} \text { with row to row } \\
\text { spacing of } 60 \mathrm{~cm} \text {. Actual field capacities of power weeder, wheel hoe and star weeder } \\
\text { were } 0.0494 \mathrm{ha} / \mathrm{h}, 0.022 \mathrm{ha} / \mathrm{h}, 0.021 \mathrm{ha} / \mathrm{h} \text { respectively. Field efficiencies of power weeder, } \\
\text { wheel hoe and star weeder are } 82.33 \%, 73.66 \%, 80.76 \% \text { respectively. Power weeder has } \\
\text { more field efficiency than other two weeders. Weeding efficiencies of power weeder, } \\
\text { wheel hoe and star weeder are } 78.4 \%, 74.0 \% \text {, and } 75.4 \% \text { respectively. Power weeder has } \\
\text { more weeding efficiency than other two weeders. Operational cost is more for power } \\
\text { weeder and less for wheel hoe, star weeder compared to power weeder. Wheel hoe is } \\
\text { having less efficiency and less cost of operation among the three weeders. Since drudgery } \\
\text { involved during weeding is more compared to other weeders hence, it could be given less } \\
\text { preference to weed when compared between power weeder and star weeder. }\end{array}$} \\
\hline Keywords & \\
\hline $\begin{array}{l}\text { Drudgery, Power } \\
\text { weeder, Wheel ho, } \\
\text { Star weeder }\end{array}$ & \\
\hline Article Info & \\
\hline $\begin{array}{l}\text { Accepted: } \\
12 \text { November } 201 \\
\text { Available Online: } \\
10 \text { December } 201\end{array}$ & \\
\hline & \\
\hline
\end{tabular}

\section{Introduction}

Weeds, instead of harbouring insects, compete with the crop for water, light and plant nutrients and adversely affect the microclimate around the plant. In the absence of an effective control measure, weeds remove $30-40 \%$ of applied nutrients resulting in significant yield reduction. Mechanical weeding is preferred considering the fact that manual weeding is time consuming, tedious and costly. Mechanical weeding is done either by power-operated weeders or manually operated weeders. Manual operated weeders have found acceptability due to their low cost but involves drudgery. Control of weeds requires lot of human labour, often several weeding are necessary to keep the crop weed free. Reduction in yield due to weed alone is estimated to be 16-42\% depending on crop and location and involves one third of the cost of cultivation (Rangaswamy et al., 1993).

Delay and negligence in weeding operation affect the crop yield and the loss in crop yields due to weeds in upland crops vary from 40-60 
per cent and in many cause complete crop failure. In India about 4.2 billion rupees are spent every year for controlling weeds in the production of major crops. At least 40 million tons of major food grains are lost every year due to weeds alone (Jagvir Dixit and lntikhab Syed, 2008). Therefore, timely weeding is very much essential for a good yield and this can only be achieved by using mechanical weeders which perform simultaneous job of weeding and hoeing and can reduce the time spent on weeding (man hours), cost of weeding and drudgery involved in manual weeding. Weeds decrease crop yields from 15 to $50 \%$ depending on species, density and weeding time through competition with main crop for light, water nutrition. It was accounted that losses due to weeds in main crops are more than 40 million tons per year. Experiments showed that competition of one kind of weed namely Echinochloa crus-gali in paddy fields reduced rice yield around $25 \%$.

Common ways for controlling weeds include mechanical, chemical, biological and agronomical ones. Mechanical control, which is performed by hand and mechanical weeder have specific importance from agronomical and conformity with environmental condition points of view. Mechanical control not only eradicates weed between rows, but also softens superficial soil and enhances aeration of soil. Depending on weed density and species in the field, labor requirement for weeding varied between 10 to 15 persons per hectare in paddy fields. Row planting technology using rice transplanter and different grain drill machines, prepared the way for utilization of such plant protection machines as weeder in paddy fields (Tajuddin, 2009).Hence, a study was conducted to evaluate the performance of three weeders (power weeder, star weeder and wheel hoe) and their cost of operation was calculated to know the low cost and efficient weeder for dry land weeding (maize field).

\section{Materials and Method}

\section{Study area}

Power weeder, star weeder and wheel hoe (Figure 1) were evaluated for its performance in the Agricultural college farm, Bapatla, which is located at latitude of $15^{\circ} 58^{\prime} \mathrm{N}$ and $80^{0} 28^{\prime}$ E longitude.

Three weeders were initially evaluated in the dry land planted with maize. Entire field was divided into equal number of plots of size $20 \mathrm{~m}$ $\times 10 \mathrm{~m}$. Row to row spacing maintained was $60 \mathrm{~cm}$, with plant to plant spacing of $15 \mathrm{~cm}$. Weeding was done at age of 25 days of maize crop. Technical information of weeders was given in Table 1.

\section{Speed of operation}

Operational speed of weeders was calculated by fixing two poles, $20 \mathrm{~m}$ apart in the test plot. The time required to travel the $20 \mathrm{~m}$ distance was recorded to calculate the average value of time. From this time the effective field capacity has been estimated.

\section{Actual field capacity}

Time consumed for real work $\left(t_{p}\right)$ and that lost for other activities such as turning at headlands, blade cleaning when clogging with weeds $\left(t_{c}\right)$ was measured by stopwatch and recorded for calculation.

$$
a=\frac{A}{\left(t_{p}+t_{c}\right)}
$$

Where,

$a=$ actual field capacity (ha/h)

$\mathrm{A}=$ area covered, ha

$\mathrm{t}_{\mathrm{p}}=$ Productive time

$\mathrm{t}_{\mathrm{c}}=$ Unproductive time, $\mathrm{h}$ 


\section{Theoretical field capacity}

It is the rate of field coverage of the implement blade on hundred per cent of time at the rated speed and covering hundred per cent of rated width. It is given by formula

$f=\frac{(W \times S)}{10}$

Where,

$f=$ theoretical field capacity $(\mathrm{ha} / \mathrm{h})$

$\mathrm{W}=$ Width $(\mathrm{m})$

$\mathrm{S}=$ Speed of operation $(\mathrm{km} / \mathrm{h})$

\section{Field efficiency}

Field efficiency is the ratio between actual field capacity and theoretical field capacity. This is calculated by using the following equation.

$$
e=\frac{\text { Actual field capacity }}{\text { Theoretical field capacity }} \times 100
$$

\section{Fuel consumption}

The fuel consumption has direct effect on economics of the power weeder. It was measured by top fill method. The fuel tank was filled to full capacity $(500 \mathrm{ml})$ before the testing at level condition. Fuel consumption was estimated by keeping the machine on a level platform and fuel was filled to full capacity mark. The amount of fuel required refilling the fuel tank again after one-hour continuous operation up to full capacity mark with help of measuring jar and fuel consumption per hour was calculated.

\section{Weeding efficiency}

Weeding efficiency was calculated by using the following formula:
$e=\frac{\left(W_{1}-W_{2}\right)}{W_{1}} \times 100$

Where,

$\mathrm{e}=$ weeding efficiency, percent

$\mathrm{W}_{1}=$ Number of weeds $/ \mathrm{m}^{2}$ before weeding

$\mathrm{W}_{2}=$ Number of weeds $/ \mathrm{m}^{2}$ after weeding

\section{Plant damage}

It is the ratio of the number of plants damaged in a row to the number of plants present in that row. It is expressed in percentage. The Plant damage was calculated by the following formula:

$q=\left\{\frac{n_{1}}{n_{2}}\right\} \times 100$

Where,

$\mathrm{q}=$ Plant damage in per cent,

$\mathrm{n}_{1}=$ Number of plants damaged in a $20 \mathrm{~m}$ row length after weeding,

$\mathrm{n}_{2}=$ Number of plants in a $20 \mathrm{~m}$ row length before weeding

\section{Cost of operation}

Cost of operation was calculated by considering depreciation, interest, housing, repair and maintenance, fuel cost and operator wages, for the power weeder where as for the wheel hoe, star weeder and traditional local tool only the operator wages are taken into consideration.

\section{Results and Discussion}

\section{Speed of operation of power weeder, Star weeder and wheel hoe}

Speeds of operation of three weeders were calculated by noting down the time required to cover $10 \mathrm{~m}$ of weeding length. Speed was calculated by calculating the average of three trails as shown in Table 2. The speed of operation of power weeder was more 
compared to star weeder and wheel hoe, because it was provided with petrol run engine which tills the soil with high rotating blades. Wheel hoe and star weeders are having almost same speeds of operations.

\section{Actual field capacity}

The actual field capacity of power weeder, star weeder and wheel hoe were observed as $0.0494,0.021$ and $0.022 \mathrm{ha} / \mathrm{h}$, respectively. The power weeder observed as highest actual field capacity when compared with the star weeder and wheel hoe. The field capacity of star weeder and wheel hoe were depending on the pulling capacity of operator (Table 3 ).

\section{Plant damage}

The plant damage with the power weeder is $11 \%$, which is more compared to star weeder and wheel hoe. Wheel hoe is having highest plant damage when compared to star weeder (Table 4).

\section{Weeding efficiency}

Weeding efficiency was calculated by counting the number of weeds in $1 \mathrm{~m}^{2}$ area before weeding and after weeding. Weeding efficiency of power weeder is $78.4 \%$, which is more compared to star weeder and wheel hoe (Fig. 2). Weeding efficiency of wheel hoe and star weeders are almost same.

\section{Cost of operation}

From Table 5, it was observed that cost of operation of power weeder was Rs. 2553 /ha. Where, wheel hoe was reported as less cost of operation, whereas drudgery is more in wheel hoe compared to power weeder and star weeder.

Table.1 Technical specifications of weeders

\begin{tabular}{|l|c|c|c|}
\hline \multicolumn{1}{|c|}{ Parameters } & $\begin{array}{c}\text { Power } \\
\text { weeder }\end{array}$ & $\begin{array}{c}\text { Star } \\
\text { weeder }\end{array}$ & Wheel hoe \\
\hline Total length $(\mathbf{c m})$ & 120 & 138 & 169 \\
\hline Handle length $\mathbf{( c m )}$ & 51 & 54 & 61 \\
\hline Wheel width $(\mathbf{c m})$ & 17 & 6 & 4 \\
\hline Cutting width $\mathbf{( c m )}$ & 25 & 17.5 & 20.5 \\
\hline Wheel diameter $\mathbf{( c m )}$ & 14 & 16 & 32 \\
\hline Weeder height $\mathbf{( c m )}$ & 80 & 93 & 135 \\
\hline No. of blades & 2 & - & - \\
\hline No. of teeth & 6 & - & - \\
\hline
\end{tabular}

Table.2 Speed of operation of power weeder, star weeder and wheel hoe

\begin{tabular}{|l|c|c|c|}
\hline Replication number & $\begin{array}{c}\text { Power weeder } \\
\text { (kmph) }\end{array}$ & $\begin{array}{c}\text { Star weeder } \\
\text { (kmph) }\end{array}$ & $\begin{array}{c}\text { Wheel hoe } \\
\text { (kmph) }\end{array}$ \\
\hline Trail 1 & 2.42 & 1.40 & 1.41 \\
\hline Trail 2 & 2.25 & 1.55 & 1.61 \\
\hline Trail 3 & 2.57 & 1.57 & 1.46 \\
\hline $\begin{array}{l}\text { Average speed } \\
\text { (kmph) }\end{array}$ & 2.41 & 1.50 & 1.49 \\
\hline
\end{tabular}


Table.3 Calculation of actual field capacity of power weeder, star weeder and wheel hoe

\begin{tabular}{|l|c|c|c|}
\hline Type of weeder & $\begin{array}{c}\text { Area of the plot (Sq. } \\
\text { m) }\end{array}$ & $\begin{array}{c}\text { Time taken to cover an } \\
\text { area of 200 sq. m (min) }\end{array}$ & $\begin{array}{c}\text { Actual Field } \\
\text { capacity (ha/h) }\end{array}$ \\
\hline Power weeder & 200 & 24 & 0.0494 \\
\hline Star weeder & 200 & 57 & 0.021 \\
\hline Wheel hoe & 200 & 54 & 0.022 \\
\hline
\end{tabular}

Table.4 Calculation of plant damage

\begin{tabular}{|l|c|c|c|}
\hline Types of weeders & $\begin{array}{l}\text { Number of plants in } \\
20 \quad \mathrm{~m} \text { row before } \\
\text { weeding }\left(\mathrm{n}_{2}\right)\end{array}$ & $\begin{array}{l}\text { Number of plants in } \\
20 \mathrm{~m} \text { row after } \\
\text { weeding }\left(\mathrm{n}_{1}\right)\end{array}$ & Plant damage (\%) \\
\hline Power weeder & 180 & 20 & 11.10 \\
\hline Star weeder & 170 & 2 & 1.17 \\
\hline Wheel hoe & 180 & 4 & 2.20 \\
\hline
\end{tabular}

Table.5 Cost of operation of three weeders in dry land (Maize crop) weeding

\begin{tabular}{|l|c|}
\hline Type of weeder & Cost of operation (Rs/ha) \\
\hline Power weeder & 2533 \\
\hline Star weeder & 1785 \\
\hline Wheel hoe & 1696 \\
\hline
\end{tabular}

Figure.1 Star weeder, wheel hoe and power weeder

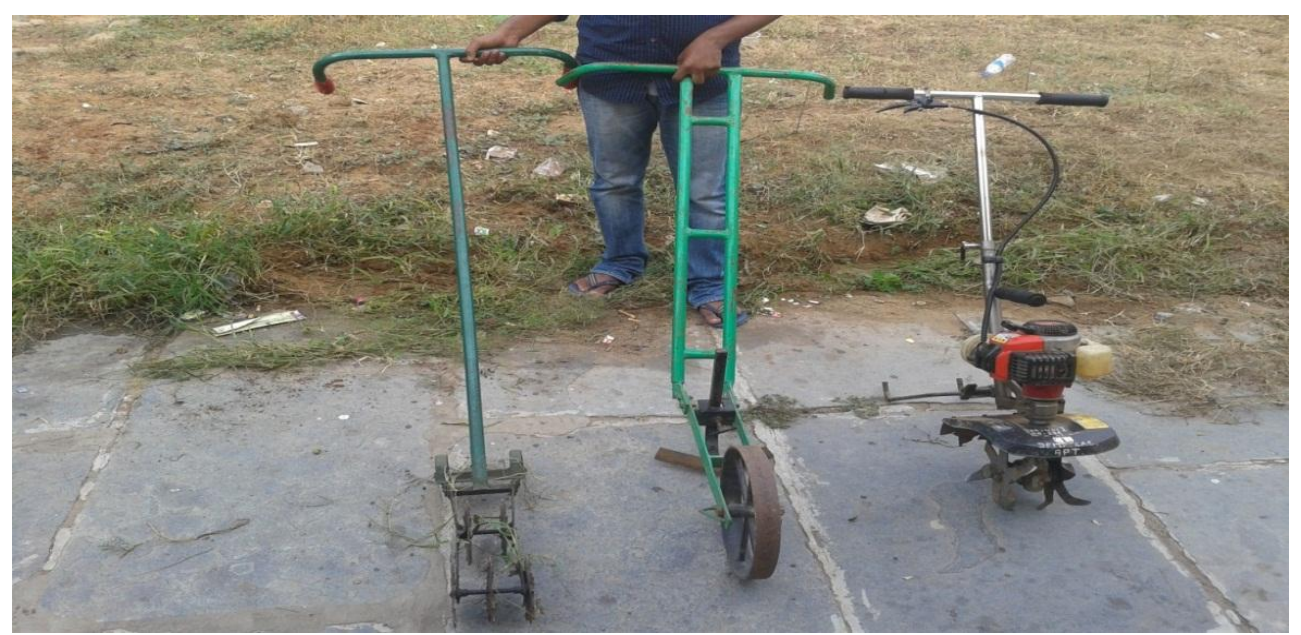


Figure.2 Weeding efficiency of power weeder, star weeder and wheel hoe

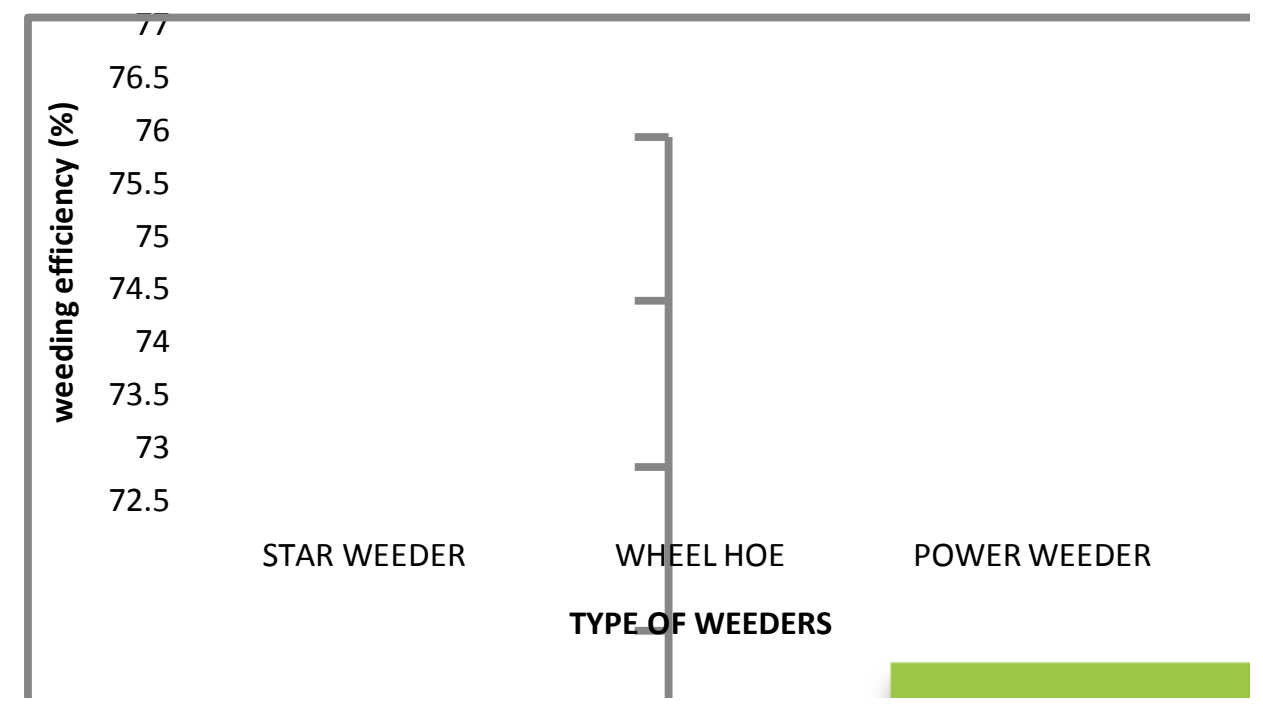

It is concluded that, field efficiency, weeding efficiency and cost of operation were more for power weeder under dry land weeding, when compared to other weeders. Even efficiency of power weeder is more; the cost of operation is a major constraint for small land holdings. Since the efficiency of power weeder and star weeder is not having much variation and also cost of operation of star weeder is less compared to power weeder. Hence it is advisable to work with star weeder and power weeder under small and higher land holding respectively. Wheel hoe is having less efficiency and less cost of operation among the three weeders. Since drudgery involved during weeding is more compared to other weeders hence, it could be given less preference to weed when compared between power weeder and star weeder.

\section{References}

Biswas, H.S. Ojha, T.P and Ingle, G.S. 1999. Development of animal drawn weeders in India. Agricultural mechanization in Asia, Africa and Latin America.34(4): 57-61.

Behera, B.K., Behera, D., Swain, S. and
Sahoo, P. K. 1996Performance Evaluation of manual weeders for paddy crop in Orissa, India. Agricultural mechanization in Asia, Africa and Latin America. 27: 20-22.

Jagvir Dixit and lntikhab Syed. 2008. Field elevation of power weeder for rain -fed crops in Kashmir valley. Agricultural mechanization in Asia, Africa and Latin America. 39(1): 53-56.

Mallikarjun Reddy, M., Reddy, C.V., Raghava Reddy, P. 2007 Status of SRI in Andhra Pradesh, problems and prospects. Proceeding of $2^{\text {nd }}$ national symposium on SRI held at ANGRAU 4446.

Manuwa, S. I., Odubanjo, O.O., Malumi, B. O and Olofinkua, S.G. 2009. Development and performance evaluation of a rowcrop mechanical weeder. Journal of engineering and applied sciences. 4(4):236-239.

Nikakini, S. O., Akor, A.J., Ayotamuno, J. M., Ikoromari, A and Efennudu, E.O. 2010.Field performance evaluation of manual operated petrol engine power weeder for the tropics. Agricultural mechanization in Asia, Africa and Latin 
America.41: 68-73.

Parida, B. sC. 2002.Development and evaluation of a star-cum-conoweeder for rice. Agricultural mechanization in Asia, Africa and latin America. 33(3):21-22.

Padole, Y.B. 2007.Performance evolution of rotary power weeder. Agricultural engineering today. 31 (3\&4): 30-33.

Rangaswamy, K. Balasubramanian, $M$ and Swaminathan, K.R. 1993. Evaluation of power weeder performance. Agricultural mechanization in Asia, Africa and Latin America. 24 (4): 16-18.
Syedal Islam, Md and Khondaker, A. H. 1991.Development of a low cost weeder for lowland paddy. Agricultural mechanization in Asia, Africa and latin America. 22(1): 45-48.

Tajuddin, A. 2006. Design, development and testing of an engine operated weeder. Agricultural engineering today. 30(5, 6): 25-29.

Tewari, V.K., Datta, R.K and Murthy, S.R. 1993. Field performance of weeding blades of a manually operated push-pull weeder. Journal of agriculture engineering. 55:129-141.

\section{How to cite this article:}

Kishore Kumar, G., B. Raj Kiran and Murali Krishna, Ch. 2018. Performance and Evaluation of Power Weeder, Wheel Hoe, Star Weederunder Dryland Conditions. Int.J.Curr.Microbiol.App.Sci. 7(12): 1669-1675. doi: https://doi.org/10.20546/ijcmas.2018.712.194 